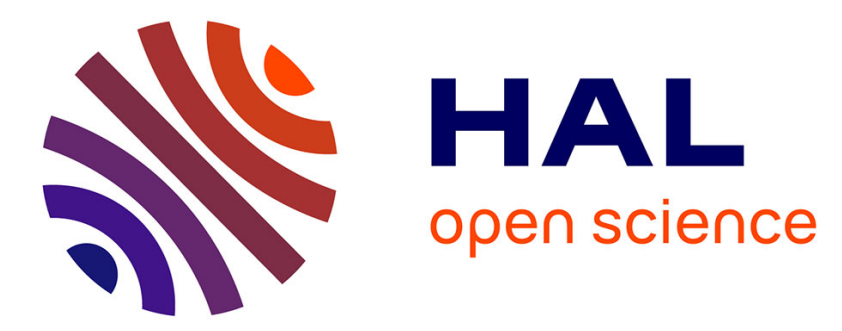

\title{
Epidemiology of pestivirus infection in wild ungulates of the French South Alps
}

Claire Martin, Carine Letellier, Brigitte Caij, Dominique Gauthier, Nicolas

Jean, Anahita Shaffii, Claude Saegerman

\section{- To cite this version:}

Claire Martin, Carine Letellier, Brigitte Caij, Dominique Gauthier, Nicolas Jean, et al.. Epidemiology of pestivirus infection in wild ungulates of the French South Alps. Veterinary Microbiology, 2010, 147 (3-4), pp.320. 10.1016/j.vetmic.2010.07.010 . hal-00654951

\section{HAL Id: hal-00654951 \\ https://hal.science/hal-00654951}

Submitted on 24 Dec 2011

HAL is a multi-disciplinary open access archive for the deposit and dissemination of scientific research documents, whether they are published or not. The documents may come from teaching and research institutions in France or abroad, or from public or private research centers.
L'archive ouverte pluridisciplinaire HAL, est destinée au dépôt et à la diffusion de documents scientifiques de niveau recherche, publiés ou non, émanant des établissements d'enseignement et de recherche français ou étrangers, des laboratoires publics ou privés. 


\section{Accepted Manuscript}

Title: Epidemiology of pestivirus infection in wild ungulates of the French South Alps

Authors: Claire Martin, Carine Letellier, Brigitte Caij, Dominique Gauthier, Nicolas Jean, Anahita Shaffii, Claude Saegerman

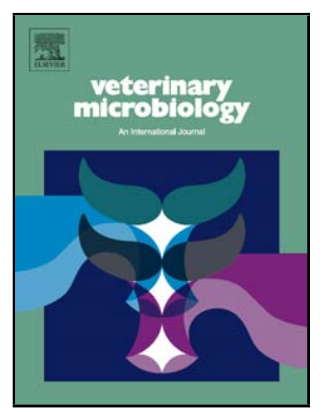

PII: S0378-1135(10)00345-7

DOI: doi:10.1016/j.vetmic.2010.07.010

Reference: VETMIC 4966

To appear in: $\quad$ VETMIC

Received date: $\quad$ 5-5-2009

Revised date: $\quad$ 5-7-2010

Accepted date: $\quad$ 16-7-2010

Please cite this article as: Martin, C., Letellier, C., Caij, B., Gauthier, D., Jean, N., Shaffii, A., Saegerman, C., Epidemiology of pestivirus infection in wild ungulates of the French South Alps, Veterinary Microbiology (2010), doi:10.1016/j.vetmic.2010.07.010

This is a PDF file of an unedited manuscript that has been accepted for publication. As a service to our customers we are providing this early version of the manuscript. The manuscript will undergo copyediting, typesetting, and review of the resulting proof before it is published in its final form. Please note that during the production process errors may be discovered which could affect the content, and all legal disclaimers that apply to the journal pertain. 


\section{Epidemiology of pestivirus infection in wild ungulates of the French South Alps}

Authors: Claire Martin ${ }^{\mathrm{a} *}$, Carine Letellier ${ }^{\mathrm{b}}$, Brigitte Caij $^{\mathrm{b}}$, Dominique Gauthier ${ }^{\mathrm{c}}$, Nicolas Jean ${ }^{\mathrm{d}}$, Anahita Shaffii ${ }^{\mathrm{e}}$, Claude Saegerman ${ }^{\mathrm{a}}$

\section{Complete postal addresses of affiliations}

${ }^{a}$ Department of Infectious and Parasitic diseases, Epidemiology and Risk Analysis Applied to

Veterinary Sciences (UREAR), Faculty of Veterinary Medicine, University of Liège, Boulevard de Colonster, 20, B42, B-4000 Liège, Belgium

${ }^{\mathrm{b}}$ Department of Virology, Veterinary and Agrochemical Research Centre (VAR-CODA-CERVA), Groeselenberg 99, B-1180 Brussels, Belgium

${ }^{\mathrm{c}}$ Laboratoire Départemental Vétérinaire et d'Hygiène Alimentaire des Hautes Alpes, rue des Silos 5, BP 63, F- 05002 GAP cedex, France

${ }^{\mathrm{d}}$ Fédération Départementale des Chasseurs des Hautes Alpes, route Sainte Marguerite 62, F-05000 Gap, France

${ }^{\mathrm{e}}$ Cyclotron Research Center, Sart-Tilman, B30, B-4000, Liège, Belgium.

* Present address: Unité de pathologie des petits ruminants, Agence nationale chargée de la sécurité sanitaire de l'alimentation, de l'environnement et du travail (ANSES), 105 Route des Chappes B.P.111, 06902 Sophia Antipolis Cedex, France

\section{Corresponding author}

Saegerman Claude, Department of Infectious and Parasitic diseases, Epidemiology and Risk Analysis Applied to Veterinary Sciences (UREAR), Faculty of Veterinary Medicine, University of Liège, Boulevard de Colonster 20, B42, B-4000 Liège, Belgium

Tel: ++32 436645 79; Fax: ++32 436642 61; E-mail address: claude.saegerman@ulg.ac.be Proofs should be sent to the address of the corresponding author. 
Abstract

Interspecies transmission is often incriminated in epidemiology of Pestivirus diseases. The purpose of this study was to investigate the prevalence of Pestivirus in some mountain wild ungulates and to determine their role in Pestivirus transmission, as mountain pastures are a place where cohabitations between wild and domestic ungulates are particularly high. Between 2003 and 2007, a longitudinal epidemiological study was carried out on hunted ungulates in the French Hautes-Alpes department. Pestivirus-specific antibodies against p80 protein (named also NS3) common to all Bovine Viral Diarrhea Virus (BVDV) and Border Disease Virus (BDV) were found in 45.9\% (95\% confidence interval [CI95\%]: 40.5-51.3\%) of the 343 tested chamois (Rupicapra rupicapra). In addition, mouflons (Ovis gmelinii musimon) were shown for the first time to be strongly infected $(61.1 \%$; CI95\%: 38.6-83.6) by a Pestivirus. These serological ELISA results were confirmed by comparative virus neutralization tests, performed on 7 Pestivirus strains by using 15 seropositive samples. The highest antibody titers were directed against 2 BDV strains (Av and 33s strains), rather than BDV-4, a strain responsible for Pyrenean-chamois epizooties. Virus neutralization tests confirm a BDV circulation in wild ungulates in the French South Alps. However, no Pestivirus RNA was detected by reverse-transcriptase polymerase chain reaction in serum and spleen samples from seronegative animals and no virus was isolated from those samples either. Efforts should be made to improve the protocol in order to be able to isolate and characterize the local strain. Finally, the oldness (age) and femaleness (gender) increase the risk of seroconversion in chamois.

\section{Keywords}

Wild ruminants, Pestivirus, Epidemiology, Alps (France), Inter-species transmission, Risk factors

4 1. Introduction

5 Pestiviruses, together with the genera Flavivirus and Hepacivirus, constitute the Flaviridae family.

56 Four species of Pestiviruses are officially accepted by the International Committee on Taxonomy of 
Viruses (ICTV): Bovine Viral Diarrhea Virus 1 (BVDV-1); Bovine Viral Diarrhea Virus 2 (BVDV2); Border Disease Virus (BDV) and Classical Swine Fever Virus (CSFV). A strain isolated from a giraffe (Giraffa cameleopardis) is tentatively classified as a species within the genus (Becher et al., 1999). The ICTV defines nucleotide sequence relatedness, serological relatedness and host of origin as the 3 main criteria for species discrimination. The subdivision between all species is also antigenically supported by poor serological cross-reactivity (Avalos-Ramirez et al., 2001).

Pestivirus are enveloped spherical viruses, 40 to $60 \mathrm{~nm}$ in diameter approximately. The genome is a positive single-stranded and nonpolyadenylated RNA molecule, $12.3 \mathrm{~kb}$ in length (Meyers and Thiel, 1996). Classification into genotypes and into species mostly relies on phylogenetic analysis, usually performed after alignment of 5'UTR, Npro or E2 sequences (Becher et al., 1999). Currently, BVDV-1 is divided into 11 genetic subgroups (Vilček et al., 2001), BVDV-2 into 2 subgroups (Vilček et al., 2005), CSFV into 3 subgroups (Paton et al., 2000) and BDV into 7 subgroups (Valdazo-Gonzalez et al., 2007).

Ruminant Pestivirus are world-wide distributed and have economically important consequences (Houe, 1999). The associated clinical signs mainly include reproductive failure such as abortion, stillbirth or decrease of fertility. The immunosuppressive effects of Pestivirus infection increase the severity of other opportunistic infections. In small ruminants, especially sheep, neurological signs, abnormal body conformation or small lambs with poor growth rate and viability are often associated with the infection (Nettleton, 2000). The presence of persistently infected animals (PI) is a very critical point to be checked before considering control measures against Pestivirus infections (Letellier and Kerkhofs, 2003).

In wildlife, Pestivirus infections have been widely described. Strains have been isolated from many artiodactyls such as camelids (Evermann, 2006); cervids (Frolich and Hofmann, 1995), and in a great number of Bovidae (Vilček and Nettleton, 2006). Hamblin and Hedger (1979) described an important seroconversion in several African bovids. In Pyrenean chamois, a recent outbreak of BDV was described, associated with a BDV-4 strain (Marco et al., 2008; Pioz et al., 2007). 
In mountain areas, common pasturing in summer seasons represents an important risk of contamination of both wild and domestic animals, either through direct contacts, or sharing same places, such as salt deposits (Richomme et al., 2006).

The goal of this study was first to investigate the seroprevalence of Pestiviruses in chamois (Rupicapra rupicapra), mouflon (Ovis gmelinii musimon) and roe deer (Capreolus capreolus) in the French South Alps and to identify the most relevant exploratory variables associated (risk factors). Then, we wanted to isolate the circulating strain(s) in order to sequence it (them) and to compare them with circulating strains already known. However, isolation of viral strains was not possible and comparative virus neutralization test (VNT) was performed in order to determine the most probable Pestivirus species circulating in the studied area.

\section{Materials and methods}

\subsection{Samples and data}

A total of 381 blood samples were collected during 2003-2007 hunting seasons from 343 chamois, 18 mouflons and 20 roe deer. Samples (blood and spleens) were collected whenever possible directly after shot by hunters themselves, or within 8 hours after shooting. Blood samples were centrifugated and sera were frozen at $-20^{\circ} \mathrm{C}$ within 12 hours after shooting. A total of 53 spleens originating from chamois only were frozen at $-20^{\circ} \mathrm{C}$ within 12 hours after their sampling. Species, sex, age, location of shot and assessment of health status of each hunted animal were given as complementary data.

\subsection{Study area}

The study was carried out in two areas located in the French South Alps, in the Hautes-Alpes department (respectively $44^{\circ} 46^{\prime} \mathrm{N}, 6^{\circ} 57^{\prime} \mathrm{E}$ and $44^{\circ} 58^{\prime} \mathrm{N}, 6^{\circ} 30^{\prime} \mathrm{E}$ ) (Figure 1). Altitudes range between $1300 \mathrm{~m}$ to $3000 \mathrm{~m}$. The first area is the Game and Wildlife National Reserve of Ristolas, located in the Queyras district and bordered in the west by the Monte Viso area, the Italian border separating these 2 areas. The second area is the Briançon district. It is composed by the Claree Valley (Val de la Clarée), the Stretta Valley (Vallée étroite), and the left-bank of Guisane Valley. They are bordered by the High Valley of Susa (Italia) in the east. Investigations were initiated in these two areas consequently of demographic troubles reported in chamois in previous years. The vegetation is a 
mixture of pine, foliage trees, larch forests and alpine pasture. Contacts may occur between chamois, mouflon, roe deer, alpine ibex (Capra ibex ibex), red deer (Cervus elaphus), and wild boar (Sus scrofa). Domestic livestock (small and large ruminants) share the pastures with wild animals during the grazing season from June to September (Figure 2).

\subsection{Serological tests}

Serological samples were screened for Pestivirus-specific antibodies against p80 protein (also named NS3), common to all BVDV and BDV strains, using a blocking enzyme linked immunosorbent assay (ELISA) (Synbiotics, Lyon, France) according to the manufacturers' recommendations.

In order to confirm positive ELISA results, a total of 53 randomly selected ELISA positive sera (49 chamois and 4 mouflons) were tested with a VNT against the BDV strain Av (Chappuis et al., 1986). Titers obtained in the 2 ELISA positive roe deer were also investigated. Besides, comparative VNT were then performed on 15 positive chamois sera (randomly chosen between all positive sera) against 7 strains: BVDV-1 strain NADL (Collett et al., 1988 ; Gen Bank accession number M31182), BVDV2 strain 3534 (Letellier and Kerkhofs, Gen Bank accession number AM181232), BDV-1 strain 137/4 (Vilček et al., 1997 ; Gen Bank accession number U65052), BDV-1 strain Frijters (Becher et al., 1997 ; Gen Bank accession number U80905), Tunisian-BDV strain 33s (Thabti et al., 2005 ; Gen Bank accession number AF462002), BDV-5 strain Av (Dubois et al., 2008 ; Gen Bank accession number EF693984), and BDV-4 strain named 02/1517. This latter strain does not have a Gen Bank accession number but was isolated in France in 2002 in Pyrenean chamois (Alzieu et al., 2004) and shares more than 99\% of genetic identity with the BDV-4 chamois-01 strain (Arnal et al., 2004, Gen Bank accession number AY738080) both in the 5' UTR and the Npro regions.

A fixed virus dose (fixed amount between 30 and 200 CCID50) was incubated for 2 hours at $37^{\circ} \mathrm{C}$ with twofold serum serial dilutions in an antibiotics enriched growth medium (i.e. penicillin, gentamicin and amphotericin B). MDBK cells (ATCC Number CCL-22) were added and the cultures were grown for 72 hours at $37^{\circ} \mathrm{C}$ in a $\mathrm{CO} 2$ incubator. All sera were tested in duplicate, using a 1:2 or a 1:10 as starting dilution. Viruses were titrated in all assays. Titers were expressed as the reciprocal of the highest serum dilution yielding virus growth neutralization. 


\subsection{Virus detection}

\subsubsection{ELISA}

Antibody negative serum samples collected between 2003 and 2006 were screened for Pestivirus specific antigens (p80) using a sandwich ELISA antigen test (Synbiotics, Lyon, France). Sera collected in 2007 were analyzed by an Erns-capture ELISA (Idexx, Liebefeld-Bern, Switzerland).

\subsubsection{RT-PCR (reverse transcription-polymerase chain reaction)}

Conventional and real-time reverse transcription-polymerase chain reactions (respectively RT-PCR and real-time RT-PCR) were performed on each serum and on each spleen, using previously described assays (Letellier et al., 1999, Letellier and Kerkhofs, 2003).

The RNA was extracted using QIAamp RNeasy® Mini kit (QIAGEN) and was resuspended in $40 \mu \mathrm{L}$ DEPC-treated water. The reverse transcription was carried out in a volume of $20 \mu 1$ containing $50 \mathrm{mM}$ Tris- $\mathrm{HCl}$ (pH 8.3), $75 \mathrm{mM} \mathrm{KCl,} 3 \mathrm{mM} \mathrm{MgCl} 2,10 \mathrm{mM}$ DTT, $0.5 \mathrm{mM}$ dNTP, $150 \mathrm{pmol}$ of the reverse primer B2, $200 \mathrm{U}$ MMLV reverse transcriptase (GIBCO BRL) and $10 \mu \mathrm{l}$ RA. The cDNA was synthesized at $37^{\circ} \mathrm{C}$ for $15 \mathrm{~min}$ and the enzyme was inactivated for $5 \mathrm{~min}$ at $95^{\circ} \mathrm{C}$. For conventional PCR, the 5'UTR region was amplified using primers BE 5' CATGCCCTTAGTAGGACTAGC 3'and B2 5'TCAACTCCATGTGCCATGTAC 3' to amplify a 287 base pair fragment. In vitro Amplification was realised in a thermocycler in a $50 \mu \mathrm{L}$ - solution containing $20 \mathrm{mM}$ Tris- $\mathrm{HCl}(\mathrm{pH}$ 8.4), $3 \mathrm{mM} \mathrm{MgCl} 2,0,5 \mathrm{mM}$ dNTP, 75 pmol of each primer, $2.5 \mathrm{u}$. Taq DNA polymerase (Invitrogen ${ }^{\circledR}$ ) and $2 \mu \mathrm{L}$ cDNA. Conditions of amplification were a first enzymatic activation for 5 min at $95^{\circ} \mathrm{C}$ followed by 35 cycles of amplification (each cycle $1 \mathrm{~min}$ at $94^{\circ} \mathrm{C}, 1 \mathrm{~min}$ at $57^{\circ} \mathrm{C}$, and $1 \mathrm{~min}$ at $72^{\circ} \mathrm{C}$ ). Amplified products were separated by electrophoresis in $1.5 \%$ agarose gel in Tris-borate EDTA buffer (Letellier et al., 1999).

For real-time RT-PCR, the primer pair F2: 5'CTCGAGATGCCATGTGGAC 3' (position 224-242 of the NADL sequence) and PESTR: 5'CTCCATGTGCCATGTACAGCA3' (position 391-371 of the NADL sequence) and the 5'FAM CAGCCTGATAGGGTGCTGCAGAGGC TAMRA 3' and the 5'VIC CACAGCCTGATAGGGTGTAGCAGAGACCTG TAMRA 3' probes were used. The Applied Biosystems ABI-PRISM 7900HT sequence detection system was used. The PCR conditions were as followed: $10^{\prime} 95^{\circ} \mathrm{C}$ and 45 cycles $15^{\prime \prime} 95^{\circ} \mathrm{C}$ and $1^{\prime} 60^{\circ} \mathrm{C}$. Fluorescent measurements were carried out 
during the elongation step. Each PCR reaction was run in $25 \mu$ l containing $2 X$ Universal Master Mix (Applied Biosystems), 300nM of both primers and 200nM of both fluorescent probes. Clinical samples were also run in the presence of TaqMan Exogenous Internal Positive Control Reagents (IPC, Applied Biosystems) in order to avoid false negative results (Letellier and Kerkhofs, 2003).

\subsubsection{Virus isolation}

All ELISA positive samples but RT-PCR negative were tested for virus isolation. Briefly, $200 \mu$ of each serum were inoculated onto duplicate wells on 24-well microtitre plates containing MDBK cells, After 1 hour of incubation at $37^{\circ} \mathrm{C}$ in $5 \% \mathrm{CO}_{2}$, the wells were drained and an antibiotics enriched growth medium (i.e. penicillin, gentamicin and amphotericin B) was added. Cultures were incubated for 5 days at $37^{\circ} \mathrm{C}$ in $5 \% \mathrm{CO}_{2}$. After cell fixation at $-20^{\circ} \mathrm{C}$, an Immuno Peroxydase Monolayer Assay was used to control presence of virus plaques.

\subsection{Statistical analysis}

The relationship between 2 qualitative variables was studied using Pearson chi squared test as a relationship statistical test (Toma et al., 2001). The apparent prevalence was standardized on age distribution in the studied population. Animals were separated in 6 groups: animals under 2 years, from 2 to 3 years, 4 to 5 years, 6 to 7 years and animals over 8 years. This allows a comparison of the epidemiological situation between different populations, as it takes into account their demographical differences (Toma et al., 2001). Wilcoxon rank sum test (Dagnelie, 1998) was used to compare optical density (OD) values. WinEpiscope ® software (Thrusfield et al., 2001) was used to calculate odds ratio (OR) in order to identify the main exploratory variables (risk factors). Adjusted odds ratio was used when zero values were observed (Grenier, 1990). Finally a logistic regression analysis was used to check the relation between the serological status of animals, their location, gender and age (Statacorp, 2007). The limit of statistical significance of the conducted tests was defined as $P \leq 0.05$. Comparison between combinations of VNT titers against each viral strain was performed using Wilcoxon signed rank test (Dagnelie, 1998), given that titers values are quantitative, paired, not normally distributed and, furthermore, that the variances were unequal. Because of the multiple comparisons of VNT titers against each viral strain, a Bonferroni correction was applied to reduce the 

risk of type I error (conservative approach); it involves dividing the $P$-value obtained with any of the test by the number of multiple comparisons performed (i.e. 21 comparisons in this study).

\section{Results}

\subsection{Descriptive epidemiology}

\subsubsection{Demographic data}

Demographic data are available for the Game and Wildlife National Reserve of Ristolas. Size of the chamois population is reported in Table I: a decrease was noticed nearly by 2004 . The reproduction rate (calculating by the number of kids divided by the number of females) is deteriorated in 20032004, and is increasing after (Table II).

\subsubsection{Serological results}

Table III presents seroprevalence according to species and years: $41 \%$ among 381 wild ungulates has antibodies against Pestiviruses.

For mouflon, 11 animals among 12 were p80 antibodies positives in 2006, whereas no other was found positive, neither in $2003(n=3)$ nor in $2007(n=3)$. OD are significantly higher for mouflon than for chamois and roe deer (Wilcoxon signed rank test, $P<0.0001$ in both case; results not shown). These ELISA positive results were confirmed by VNT, according to a survey on four ELISA positive sera randomly chosen. Neutralizing antibodies titers against the BDV Av strain ranged from 1:128 to 1:512. For roe deer, only 2 were antibodies positive among 20 tested, in 2003 (Table III). Titers obtained in VNT were for the first one superior to 1:256 and, for the second one, inconclusive results (toxicity until 1:4 and negative results from 1:8). Nevertheless, considering the small effective of roe deer and mouflon, all following results are given for the chamois species only.

For chamois, the high size of the samples allows to standardize apparent prevalence on age distribution and to study related risk factors. Among 338 samples (age is unknown in 5 animals) collected between 2003 and 2007, 45.9\% (95\%CI: 40.5-51.4\%) were tested positive with the p80 Pestivirus antibodies ELISA test. Forty nine of these positive sera were randomly chosen and tested by 
VNT (using BDV-Av strain): all were confirmed positive. Values of apparent prevalence ranged from 60.6\% in 2003 (CI95\%: 42.1-77.1\%) to 36.5\% in 2007 (95\% CI: 25.6-48.5\%). Apparent prevalence evolution in function of the chamois birth year (determined by horn ring-counting) is represented on figure 3. The apparent prevalence is steadily going down. Interestingly, the prevalence drop every 4 years $(1997,2001$ and 2005).

In the VNT directed against Av-strain, mean titers obtained in 2007 amounted to 7857 (Standard Error, S.E.: 3038) and were higher than those obtained either in 2003 (Mean=267; S.E=152), in 2004 $($ Mean=238; S.E=109) or in 2006 (Mean=269; S.E=50).

\subsubsection{Virological results}

Antigen ELISA was only performed on seronegative samples. In 2004 all tested samples were positive for Pestivirus antigen (apparent prevalence: 100\%; 95\% CI: 85-100\%) whereas no antigen was detected in 2005 (95\%CI: 0-8\%). In 2006 and 2007, respectively 2.6\% (95\% CI: $0.3-9 \%$ ) and $7.8 \%$ (95\% CI: 3.51-11.87\%) of the tested animals were positive. Nevertheless, no Pestivirus was detected using RT-PCR either in seropositive and seronegative sera or in the spleens tested (no spleens were available in 2004). No virus was isolated in cell culture.

\subsection{Analytical epidemiology}

\subsubsection{Apparent seroprevalence related factors}

Seroprevalence was significantly lower in younger chamois $(\mathrm{OR} \leq 2 \mathrm{years}=0.40 ; 95 \% \mathrm{CI}: 0.25-0.63)$ than in older animals. The risk to be seropositive significantly increased in older animals: OR $>8 y e a r s=$ 2.90 (95\% CI: 1.74-4.82). In addition, the p80 antibodies prevalence is significantly higher in females than in males $(\mathrm{OR} Q=2.39 ; 95 \% \mathrm{CI}: 1.50-3.80)$. There is a significant difference between the 2 studied areas: the apparent prevalence was higher in the Briançon district than in the Queyras district (OR Briançon $=1.62(95 \%$ CI: 1.05-2.51). However, the seroconversion status of animals was assessed in function of the location, the gender and the age of animals using a logistic regression. In fact, only the oldness (age) and femaleness (gender) increase the risk of seroconversion in chamois.

\subsubsection{Comparative VNT}

VNT titers were obtained against 7 Pestivirus strains and are reported in Table IV. 
The Wilcoxon signed rank test was performed on the data sets (21 different combinations were tested) and the results showed that Av and 33s titers are higher than those obtained for each of the remaining strain (Table V). However, the difference between Av and 33s is not significant (Wilcoxon signed rank test, $P=0.28$ ). Titers against the BVDV-2 3534 strain were significantly lower than those against all other strains (Wilcoxon signed rank test with Bonferroni correction, $P<0.001$ in each case) demonstrating that the circulating virus could probably not be classified as BVDV-2 genotype. Nevertheless, there is no significant difference among the NADL, Frijers, $137 / 4$ and 02/11517 strains (Figure 4).

\section{Discussion}

The presence of pestivirus infection in chamois and mouflons, investigated by serological ELISA tests, and confirmed in VNT, is obvious. For mouflon, it's the first published description of pestivirus positive seroprevalence confirmed by VNT.

At methodological level, p80 Pestivirus antibodies ELISA test appears to be an excellent sensitive screening tool for these wild ungulates, as $100 \%$ of positive sera were confirmed by VNT. Infection seems to be of major impact in 2003 and 2004, both with population downfall and with detection antigen positive animals in Ristolas in 2004. Then, it is important to know if the circulating strain is indigenous among wild ungulates like in the Pyrenean chamois, or if the strain is shared between wild and domestic ungulates. Indeed, in the Pyrenean Mountains, several Pestivirus strains all clustered in the BDV-4 genotype are circulating (Marco et al., 2008; Pioz et al., 2007).

For direct viral detection, positive antigen ELISA results suggested that a pestivirus strain was circulating especially in 2004; unfortunately, these results could not be confirmed by the RT-PCR test. Three hypotheses could explain these diverging results.

The first hypothesis is the degradation of samples quality during freezing storage process. Indeed, RNA labile nature has already been pointed (Blacksell et al., 2004). Some RNA storage methods such as the use of guanidinium compounds (Dubois et al., 2008) or RNAlaterTM have to be evaluated. The higher titers obtained in 2007 with VNT using Av strain, compared to others years, may be another index. Then, in 2004, no spleens were available while the p80 antigen ELISA (prevalence antigen) 
was the highest. It was therefore impossible to use this organ of choice to confirm these results. Another hypothesis is the lack of specificity of the antigen ELISA test when performed on wild ruminants serum samples. Indeed, for two chamois shot in 2007, the virus status of the animals (determined with an antigen ELISA test performed on serum samples) were not confirmed by the RTPCR carried out on the corresponding spleens, even if samples were adequately stored. This underlines the problem of commercial kits use in conditions different from those recommended by the manufacturers. This is in accordance with a previous study conducted on Pyrenean chamois by Marco et al., (2008); 4 samples on 18 were false positive with antigen ELISA test manufactured by Synbiotics firm. Sensitivity and specificity of the commercial tests used are therefore known for domestic animals only. Moreover, in this study, sera samples were collected in dead animals, within 12 hours after shooting. Specificity and sensitivity values are therefore lower than in live animals (Olde Riekerink et al., 2005).

The RT-PCR method, considered as reference in this study, has been previously performed on various Pestivirus strains. All the results provided by real time RT-PCR were in concordance with conventional PCR. At least 60 strains can be detected by this test, classified in the 4 Pestivirus species (BVDV-1, BVDV-2, BDV including a BDV-4 virus isolated from Pyrenean chamois or CSFV). This test was thus suitable to detect unknown Pestivirus strains, like in wild animals (Letellier and Kerkhofs, 2003).

Since we were not able to isolate the local strains, comparative VNT against different Pestivirus strains were performed in order to characterize the local strain antigenically. There could be a bias in the comparative VNT conclusions as the 15 selected sera were randomly chosen among all samples with titers against Av superior to 1/128. Av strain was chosen as reference strain for the initial VNT for several reasons. First of all, a BDV strain was preferred to a BVDV strain as chamois are phylogenetically closer to sheep and goats than to bovines. Then, a recent study performed in Pyrenean chamois (Rupicapra pyrenaica pyrenaica) showed that a BDV-4 was enzootic (Pioz et al., 2007). Among all BDV strains available in this study, we chose the Av strain, mainly for geographical reasons. 137/4 strain was isolated from sheep in the United Kindom (Vilček et al., 1997), Frijters from pigs in Germany (Vilček and Belak, 1996), and 33s in Tunisians vaccines (Thabti et al., 2005). Strains 
Av and 02/1517 were isolated in France and Av strain comes from an acute Border Disease outbreak of Aveyon department in 1985 (Dubois et al., 2008). The 02/1517 strain was isolated in a Pyrenean chamois (Letellier, personal communication). Vilček Dubois et al. (2008) showed that an Alpine mountain strain isolated in 1993 from sheep was closely related to the Av strain. Assuming that a contamination could come from domestic ungulates in a same pasture, we chose Av strain as reference. However, construction of a dendrogram based on antigenic coefficient similarities (Archetti and Horsfall, 1950) was not possible, due to the unavailability of isolated circulating strain. Our comparative VNT results tend to show that this strain may be classified into the BDV genotype. Indeed, significantly lower titers were obtained against the 3534 strain, indicating that the circulating virus was not clustered in the BVDV-2 species. Then, Av and 33s strains, 2 BDV strains, were more neutralized than the other ones. Although these results are not significant with Bonferroni correction, they are of great importance. In France, ovine Pestivirus strains distribution has only been published by Dubois and collaborators (2008). They sequenced 23 of 32 strains isolated between 1985 and 2006 in 4 French districts. Thirteen ovine strains circulating in PACA (Provence Alpes Côte d'Azur) regions were classified among BDV-3, BDV-5, BDV-6 and Tunisian genotypes. Among these 13 strains, 3 are especially relevant. The first was collected in the Alpine mountains in 1993 (named 93F-7289), and clustered with the Av strain. The 2 other ovine isolate, collected in 1996 in Vaucluse (one of the 6 PACA departments), clustered with the Tunisians isolates (Dubois et al., 2008). Thus, our results feel with this description. The circulating strain seems to be quite different from the Pestivirus strain circulating among the Pyrenean chamois population, as titers directed against 02/1517 are lower than those obtained against Av and 33s. Interactions are frequently observed between wild and domestic ungulates, mainly on salt points during grazing season (Richomme et al., 2006). In this region, small ruminants herds are in contact with wild populations analyzed (e.g., in Ristolas, around 7500 sheep and 50 goat were present in all pastures) and may have played an important role in the transmission of Pestiviruses. This can be confirmed by the assumption made by Olde Riekerink and collaborators, in 2005. Unfortunately, analysis of seroprevalence and circulating strains among domestic ruminants could not be included in this study.

The prevalence of Pestivirus antibodies based on the animals year of birth has been decreasing since 
1991. It is interesting to note the presence of a regular, acute decrease every 4 years $(1997,2001$ and 2005). This could be explained by the circulation of a Pestivirus strain, which could be enzootic, with periodical active circulation periods, or by more appropriated samples conservation since 2007. One fifth of the youngest animals have antibodies. On average, juveniles are 6 months old at the time of sampling which is the limit of colostral antibodies duration in cattle. It is thus difficult to assume whether they are still under colostral protection or have their own antibodies. However, $29.5 \%$ (95\% CI: $16.8-45.2 \%$ ) of the chamois yearlings are seropositive. This confirms the hypothesis of a recent circulation of a Pestivirus. This is also supported by 2 epidemiological studies conducted in the Pyrenean Mountains, in which a Pestivirus seems to be enzootic in the Pyrenean chamois populations, either in France or in Spain (Marco et al., 2008; Pioz et al., 2007). In Lecco province, in the Italian Alpine mountains, Citterio and collaborators (2003) have shown the absence of seroconversion in 145 chamois during 2000 and 2001 hunting seasons (95\% CI: 0-2\%). However, in 1999, in the High Valley of Suza, an Italian bordering valley of the Briançon district, 25.5\% of 110 tested chamois were seropositive (95\% CI: 17.6-34.6\%) either with an ELISA test or with a VNT (Olde Rieckerink et al., 2005). Titers obtained in Suza valley are significantly lower than those obtained in our study (data not shown), which could indicate either that the origin of contamination are located in France, or that the apparent prevalence has increased since 1999. Another hypothesis is that the BDV strain used in the VNT was antigenically different from the circulating Pestivirus.

Haydon et al. (2002) defined a reservoir as "one or more epidemiologically connected populations or environments in which the pathogen can be permanently maintained and from which infection is transmitted to the defined target population". This study showed that wild ungulates are widely seropositive for Pestivirus. High number of mouflons was seropositive with high OD values. They were introduced in the Hautes-Alpes department between 1973 and 1977 from populations originated of Bauges Reserve; themselves coming from Corsican Mouflon (Gauthier, personal communication). In zoological classification, they are the closest species to sheep among all wild ungulates present in the study area. We can thus imagine that mouflons are playing an important role in the disease transmission. All others ungulates (cervids and Capra ibex) should also be added to improve the study design with special emphasis on mouflons. The first next step to this study is to associate a study of 
domestic animals infection. To understand epidemiology of Pestivirus infections at the wild and domestic ruminant interface, further studies are needed to know the Pestivirus prevalence among domestic herds and to characterize the circulating strain in both wild and domestic ungulates.

\section{Conclusion}

A high seroprevalence against Pestivirus was shown among chamois, and, for the first time, mouflon in the South of French Alpine Mountains. These results were confirmed by VNT in favour of BDV circulation in wild ungulates in the French South Alps. However, no Pestivirus RNA was detected by reverse-transcriptase polymerase chain reaction in samples and no virus was isolated either. As mountain pastures are a place where cohabitations between wild and domestic ungulates are particularly high (especially sheep), there is a wide probability that the circulating strain clusters within the BDV genotype. The high seroprevalence associated with positive VNT and lack of isolation in wild ungulates could suggest a domestic origin of infection. To assess the importance of circulation among domestic animals and to know the role of each species in the transmission of the pathogen, further epidemiological (viral and serological) and transversal studies are needed.

\section{Acknowledgements}

We would like to thank all hunters and wildlife actors in the study area which permitted the conducting of this study. We are most grateful to Anahita Shaffii for her English improvement. This study was funded by the hunters' federation, the departmental veterinary laboratory of the HautesAlpes French department, the Veterinary and Agrochimical Research Center of Brussel and a research grant of the University of Liege.

\section{References}


Alzieu, J.P., Deplanche, M., Moulignie, M., Letellier, C., Lacroux, C., Duquesnel, R., Baranowski, E., Meyers, G., Kerkhofs, P., Schelcher, F., 2004. First description of pestivirus infection in Rupicapra pyrenaica pyrenaica. Bull. Acad. Vet. France 157, 49-54.

Archetti, I., Horsfall, F.L., 1950. Persistent antigenic variation of influenza A viruses after incomplete neutralization in ovo with heterologous immune serum. J. Exp. Med. 92, 441-462.

Arnal, M.C., Fernandez-de-Luco, D., Riba, L., Maley, M., Gilray, J., Willoughby, K., Vilček, S., Nettleton, P.F., 2004. A novel pestivirus associated with deaths in Pyrenean chamois (Rupicapra pyrenaica pyrenaica). J. Gen. Virol. 85, 3653-3657.

Avalos-Ramirez, R., Orlich, M., Thiel, H.J., Becher, P., 2001. Evidence for the presence of two novel pestivirus species. Virology 286, 456-465.

Becher, P., Orlich, M., Kosmidou, A., Konig, M., Baroth, M., Thiel, H.J., 1999. Genetic diversity of pestiviruses: identification of novel groups and implications for classification. Virology 262, 64-71.

Becher, P., Orlich, M., Shannon, A.D., Horner, G., König, M., Thiel, H.J.,1997. Phylogenetic analysis of Pestiviruses from domestic and wild ruminants. J. Gen. Virol. 78, 1357-1366.

Blacksell, S.D., Khounsy, S., Westbury, H.A., 2004. The effect of sample degradation and RNA stabilization on classical swine fever virus RT-PCR and ELISA methods. J. Virol. Methods 118, 33 37.

Chappuis, G., Brun, A., Kato, F., Dauvergne, M., Reynaud G., Duret, C., 1986. Etudes sérologiques et immunologiques réalisées à la suite de l'isolement d'un pestivirus dans un foyer ovina chez des moutons. In: Pestiviroses des ovins et des bovins. J. Espinasse, M. Savey, Sociéte française de buiatrie, pp. 55-66.

Citterio, C.V., Luzzago, C., Sala, M., Sironi, G., Gatti, P., Gaffuri, A., Lanfranchi, P., 2003. Serological study of a population of alpine chamois (Rupicapra $r$ rupicapra) affected by an outbreak of respiratory disease. Vet. Rec. 153, 592-596.

Collett, M.S., Larson, R., Gold, C., Strick, D., Anderson, D.K., Purchio, A.F., 1988. Molecular cloning and nucleotide sequence of the pestivirus bovine viral diarrhea virus. Virology 165, 191-199.

Dagnelie, P., 1998. Interférence statistique à une et à deux dimensions. In Statistique théorique et appliquée. Volume 2. Paris, Brussels: De Boeck \& Larcier, pp. 659. 
Dubois, E., Russo, P., Prigent, M., Thiéry, R., 2008. Genetic characterization of ovine pestiviruses isolated in France, between 1985 and 2006. Vet. Microbiol. 130, 69-79.

Evermann, J.F., 2006. Pestiviral infection of llamas and alpacas. Small Ruminant Res. 61, 201-206.

Frölich, K., Hofmann, M., 1995. Isolation of bovine viral diarrhea virus-like pestiviruses from roe deer (Capreolus capreolus). J. Wild. Dis. 31, 243-246.

Grenier, B. 1990. Analyse et stratégie de la décision médicale. Editions Masson, Paris, 246 pages.

Hamblin, C., Hedger, R.S., 1979. The prevalence of antibodies to bovine viral diarrhoea/mucosal disease virus in African wildlife. Comp. Immunol. Microbiol. Infect. Dis. 2, 295-303.

Haydon, D. T.; Cleaveland, S.; Taylor, L. H.; Laurenson, M. K. 2002. Identifying reservoirs of infection: a conceptual and practical challenge. Emerg. Infect. Dis. 8, 1468-1473.

Houe, H., 1999. Epidemiological features and economical importance of bovine virus diarrhoea virus (BVDV) infections. Vet. Microbiol. 64, 89-107.

Letellier, C., Kerkhofs, P., 2003. Real-time PCR for simultaneous detection and genotyping of bovine viral diarrhea virus. J. Virol. Methods 114, 21-27.

Letellier, C., Kerkhofs, P., Wellemans, G., Vanopdenbosch, E., 1999. Detection and genotyping of bovine diarrhea virus by reverse transcription-polymerase chain amplification of the 5 ' untranslated region. Vet. Microbiol. 64, 155-167.

Marco, I., Rosell, R., Cabezon, O., Mentaberre, G., Casas, E., Velarde, R., Lopez-Olvera, J.R., Hurtado, A., Lavin, S., 2008. Epidemiological study of border disease virus infection in Southern chamois (Rupicapra pyrenaica) after an outbreak of disease in the Pyrenees (NE Spain). Vet. Microbiol. 127, 29-38.

Meyers, G., Thiel, H. J., 1996. Molecular characterization of pestiviruses. Adv. Virus Res. 47, 53-118. Nettleton, P.F., 2000, Border disease, In: Diseases of sheep. Blackwell Science, Oxford UK, pp. 95102.

Olde Riekerink, R.G.M., Dominici, A., Barkema, H.W., de Smit, A.J., 2005. Seroprevalence of pestivirus in four species of alpine wild ungulates in the High Valley of Susa, Italy. Vet. Microbiol. 108, 297-303. 
Paton, D.J., McGoldrick, A., Greiser-Wilke, I., Parchariyanon, S., Song, J.Y., Liou, P.P., Stadejek, T., Lowings, J.P., Bjorklund, H., Belak, S., 2000. Genetic typing of classical swine fever virus. Vet. Microbiol. 73, 137-157.

Pioz, M., Loison, A., Gibert, P., Dubray, D., Menaut, P., Le Tallec, B., Artois, M., Gilot-Fromont, E., 2007. Transmission of a pestivirus infection in a population of Pyrenean chamois. Vet. Microbiol. 119, 19-30.

Richomme, C., Gauthier, D., Fromont, E., 2006. Contact rates and exposure to inter-species disease transmission in mountain ungulates. Epidemiol. Infect. 134, 21-30.

StataCorp, 2007. Stata Statistical Software: Release 10. College Station, TX. 333 StataCorp LP. Thabti, F., Letellier, C., Hammami, S., Pepin, M., Ribiere, M., Mesplede, A., Kerkhofs, P., Russo, P., 2005. Detection of a novel border disease virus subgroup in Tunisian sheep. Arch. Virol. 150, 215229.

Thrusfield M., Ortega C., de Blas I., Noordhuizen J.P., Frankena, K. 2001. WINEPISCOPE 2.0: improved epidemiological software for veterinary medicine. Vet Rec., 148, 567-572.

Toma, B., Dufour, B., Sanaa, M., Benet, J.J., Shaw, A., Moutou, F., Louza, A., 2001. Notion de base en épidémiologie, In: AEEMA (Ed.) Epidémiologie appliquée à la lutte collective contre les maladies transmissibles majeures.Maisons-Alfort, pp. 29-35.

Valdazo-Gonzalez, B., Alvarez-Martinez, M., Sandvik, T., 2007. Genetic and antigenic typing of border disease virus isolates in sheep from the Iberian Peninsula. Vet. J. 174, 316-324.

Vilček, S., Belak, S., 1996. Genetic identification of pestivirus strain Frijters as a border disease virus from pigs. J. Virol. Methods 60, 103-108.

Vilček, S., Durkovic, B., Kolesarova, M., Paton, D.J., 2005. Genetic diversity of BVDV: consequences for classification and molecular epidemiology. Prev. Vet. Med. 72, 31-35.

Vilček, S., Nettleton, P.F., 2006. Pestiviruses in wild animals. Vet. Microbiol. 116, 1-12.

Vilček, S., Nettleton, P.F., Paton, D.J., Belak, S., 1997. Molecular characterization of ovine pestiviruses. J. Gen. Virol. 78, 725-735. 
470 Vilček, S., Paton, D.J., Durkovic, B., Strojny, L., Ibata, G., Moussa, A., Loitsch, A., Rossmanith, W.,

471 Vega, S., Scicluna, M.T., Palfi, V., 2001. Bovine viral diarrhoea virus genotype 1 can be separated 472 into at least eleven genetic groups. Arch. Virol. 146, 99-115.

473

474

475 


\section{Figures and Tables}

477

478

479

480

481

482

483

484

485

486

487

488

489

490

491

492

493

494

495

496

497

498

499

500

501

502

503
Figure 2

Title: Phylogeny of ruminants presents in the study area

Legend:

Scientific names were taken from the NCBI Taxonomy Database (http://www.ncbi.nlm.nih.gov/taxonomy; consulted on November, $8^{\text {th }}$ of 2009).

\section{Figure 3}

Title: Annual evolution of the standardized apparent prevalence rate $(\square)$ in chamois (Rupicapra rupicapra) originating from the French South Alps with $95 \%$ confidence interval (-)* of the Pestivirus p80 antibodies.

Legend: The standardization of the apparent prevalence has been calculated in function of the age on the chamois, considering 5 strates: 0-2 years, 2-4 years, 4-6 years, 6 to 8 years and more than 8 years ; * exact $95 \%$ binomial confidence intervals

\section{Figure 4}

Title: Boxplot representation of the titer logarithm ( $\mathrm{Y}$ axis) obtained against each viral strain (X axis)

\section{Table I}

Title: Estimations of population size of the chamois population in the Game and Wildlife National Reserve of Ristolas

Legend: * Not realized for meteorological reasons 
505 Title: Reproduction rate in the chamois population in the Game and Wildlife National Reserve of 506 Ristolas

507 Legend: reproduction rate $=\mathrm{kid} / \mathrm{female}$ rate

508

509

\section{Table III}

510 Title: Annual and species repartition of all blood samples

511 Legend: In bracket values are the ELISA positive samples for Pestivirus antibodies.

512

\section{Table IV}

514 Title: Virus neutralization titers on 15 chamois (Rupicapra rupicapra) originating from the French

515 South Alps for 7 Pestivirus strains

516 Legend: $\mathrm{F}=$ female, $\mathrm{M}=$ male, n.d.: data not available.

517

\section{Table V}

519 Title: Arithmetic mean and standard error of titers obtained for each virus strain and $P$ value obtained

520 with the Wilcoxon signed rank test

521 Legend: *Significant value after Bonferroni’s correction $(P<0.002)$

522

523 


\section{Table I}

2

\begin{tabular}{ccc}
\hline Year & Population size \\
\hline 1986 & 415 & \\
1989 & 469 & \\
1992 & 510 & \\
1995 & - & $*$ \\
1998 & 729 & \\
2001 & - & $*$ \\
2004 & 344 & \\
2006 & 268 & \\
\hline
\end{tabular}

3

4 


\section{Table II}

2

\begin{tabular}{cc}
\hline Year & Reproduction index \\
\hline 2002 & 0.61 \\
2003 & 0.56 \\
2004 & 0.56 \\
2005 & 0.68 \\
2006 & 0.76 \\
2007 & 0.85 \\
\hline
\end{tabular}

3

4 
1 Table III

2

\begin{tabular}{lcccccc}
\hline & 2003 & 2004 & 2005 & 2006 & 2007 & Total \\
\hline Chamois & $33(18)$ & $60(35)$ & $42(13)$ & $131(53)$ & $77(26)$ & $343(145)$ \\
Mouflon & $3(0)$ & - & - & $12(11)$ & $3(0)$ & $18(11)$ \\
Roe deer & $6(2)$ & - & - & $1(0)$ & $13(0)$ & $20(2)$
\end{tabular}

3

4 


\section{Table IV}

\begin{tabular}{|c|c|c|c|c|c|c|c|c|c|}
\hline \multirow{2}{*}{ Serum } & \multirow{2}{*}{$\begin{array}{c}\text { Age } \\
\text { (year) }\end{array}$} & \multirow{2}{*}{ Sex } & \multicolumn{7}{|c|}{ Strain } \\
\hline & & & $\mathrm{Av}$ & $33 \mathrm{~s}$ & $02 / 1517$ & Frijters & $137 / 4$ & NADL & 3534 \\
\hline 3.N.5 & 2 & $\mathrm{~F}$ & 128 & 13 & 20 & 0 & 40 & 1024 & 0 \\
\hline 3.N.25 & 14 & M & 1024 & 5120 & 640 & 2560 & 2560 & 2048 & 160 \\
\hline 5.R.13 & 2 & M & 20480 & 10240 & 1280 & 2560 & 640 & 4096 & 320 \\
\hline 5.R.27 & 10 & M & 512 & 320 & 80 & 160 & 320 & 512 & 80 \\
\hline 5.R.30 & 6 & M & 256 & 320 & 160 & 1280 & 640 & 32 & 16 \\
\hline 6.N.1 & 8 & F & 512 & 160 & 40 & 80 & 160 & 8 & 4 \\
\hline 6.N.2 & 13 & $\mathrm{~F}$ & 256 & 640 & 320 & 640 & 640 & 128 & 0 \\
\hline 6.R.10 & 3 & M & 1024 & 1280 & 640 & 640 & 640 & 256 & 80 \\
\hline 6.B.7 & 0 & M & 256 & 320 & 40 & 160 & 80 & 3 & 6 \\
\hline 7.V.40 & n.d. & n.d. & 20480 & 10240 & 10240 & 5120 & 1280 & 5120 & 160 \\
\hline 7.V.42 & 10 & $\mathrm{~F}$ & 20480 & 20480 & 10240 & 10240 & 5120 & 20480 & 320 \\
\hline 7.V.46 & 0 & M & 20480 & 5120 & 10240 & 2560 & 1280 & 5120 & 320 \\
\hline 7.N.4 & n.d. & n.d. & 4096 & 5120 & 640 & 640 & 1280 & 320 & 80 \\
\hline 7.N.13 & n.d. & n.d. & 20480 & 10240 & 1280 & 5120 & 320 & 2560 & 80 \\
\hline 7.N.59 & 18 & $\mathrm{~F}$ & 1024 & 640 & 320 & 320 & 320 & 80 & 0 \\
\hline
\end{tabular}


2

\begin{tabular}{|c|c|c|c|c|c|c|}
\hline \multirow[b]{2}{*}{ Strain 1} & \multirow[b]{2}{*}{$(\mathrm{Mean} \pm \mathrm{SE})$} & \multirow[b]{2}{*}{$v s$} & \multirow[b]{2}{*}{ Strain 2} & \multirow[b]{2}{*}{$($ Mean \pm SE $)$} & \multicolumn{2}{|c|}{ Wilcoxon } \\
\hline & & & & & $\begin{array}{l}\text { signed } \\
\text { test } P \text { val }\end{array}$ & rank \\
\hline $\mathrm{Av}$ & $(7432,53 \pm 2125,47)$ & - & NADL & $(2785,8 \pm 1198,95)$ & 0,02 & \\
\hline Av & $(7432,53 \pm 2125,47)$ & - & 3534 & $(108,4 \pm 29,78)$ & $<0,001$ & * \\
\hline Av & $(7432,53 \pm 2125,47)$ & - & $02 / 1517$ & $(2412 \pm 722,09)$ & $<0,001$ & * \\
\hline Av & $(7432,53 \pm 2125,47)$ & - & $33 \mathrm{~s}$ & $(4683,53 \pm 1216,67)$ & 0,28 & \\
\hline Av & $(7432,53 \pm 2125,47)$ & - & Frijters & $(2138,67 \pm 547,98)$ & 0,028 & \\
\hline Av & $(7432,53 \pm 2125,47)$ & - & $137 / 4$ & $(1021,33 \pm 322,90)$ & 0,027 & \\
\hline NADL & $(2785,8 \pm 1198,95)$ & - & 3534 & $(108,4 \pm 29,78)$ & $<0,001$ & $*$ \\
\hline NADL & $(2785,8 \pm 1198,95)$ & - & $02 / 1517$ & $(2412 \pm 722,09)$ & $<0,001$ & $*$ \\
\hline NADL & $(2785,8 \pm 1198,95)$ & - & $33 \mathrm{~s}$ & $(4683,53 \pm 1216,67)$ & 0,009 & \\
\hline NADL & $(2785,8 \pm 1198,95)$ & - & Frijters & $(2138,67 \pm 547,98)$ & 0,86 & \\
\hline NADL & $(2785,8 \pm 1198,95)$ & - & $137 / 4$ & $(1021,33 \pm 322,90)$ & 0,31 & \\
\hline 3534 & $(108,4 \pm 29,78)$ & - & $02 / 1517$ & $(2412 \pm 722,09)$ & $<0,001$ & $*$ \\
\hline 3534 & $(108,4 \pm 29,78)$ & & $33 \mathrm{~s}$ & $(4683,53 \pm 1216,67)$ & $<0,001$ & $*$ \\
\hline 3534 & $(108,4 \pm 29,78)$ & - & Frijters & $(2138,67 \pm 547,98)$ & $<0,001$ & $*$ \\
\hline 3534 & $(108,4 \pm 29,78)$ & - & $137 / 4$ & $(1021,33 \pm 322,90)$ & $<0,001$ & $*$ \\
\hline $02 / 1517$ & $(2412 \pm 722,09)$ & - & $33 \mathrm{~s}$ & $(4683,53 \pm 1216,67)$ & 0,009 & \\
\hline $02 / 1517$ & $(2412 \pm 722,09)$ & - & Frijters & $(2138,67 \pm 547,98)$ & 0,227 & \\
\hline $02 / 1517$ & $(2412 \pm 722,09)$ & - & $137 / 4$ & $(1021,33 \pm 322,90)$ & 0,819 & \\
\hline $33 \mathrm{~s}$ & $(4683,53 \pm 1216,67)$ & - & Frijters & $(2138,67 \pm 547,98)$ & 0,003 & \\
\hline $33 \mathrm{~s}$ & $(4683,53 \pm 1216,67)$ & - & $137 / 4$ & $(1021,33 \pm 322,90)$ & 0,008 & \\
\hline Frijters & $(2138,67 \pm 547,98)$ & - & $137 / 4$ & $(1021,33 \pm 322,90)$ & 0,135 & \\
\hline
\end{tabular}

\section{(Table V}

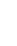




\section{$1 \quad$ Figure 1}

2

3

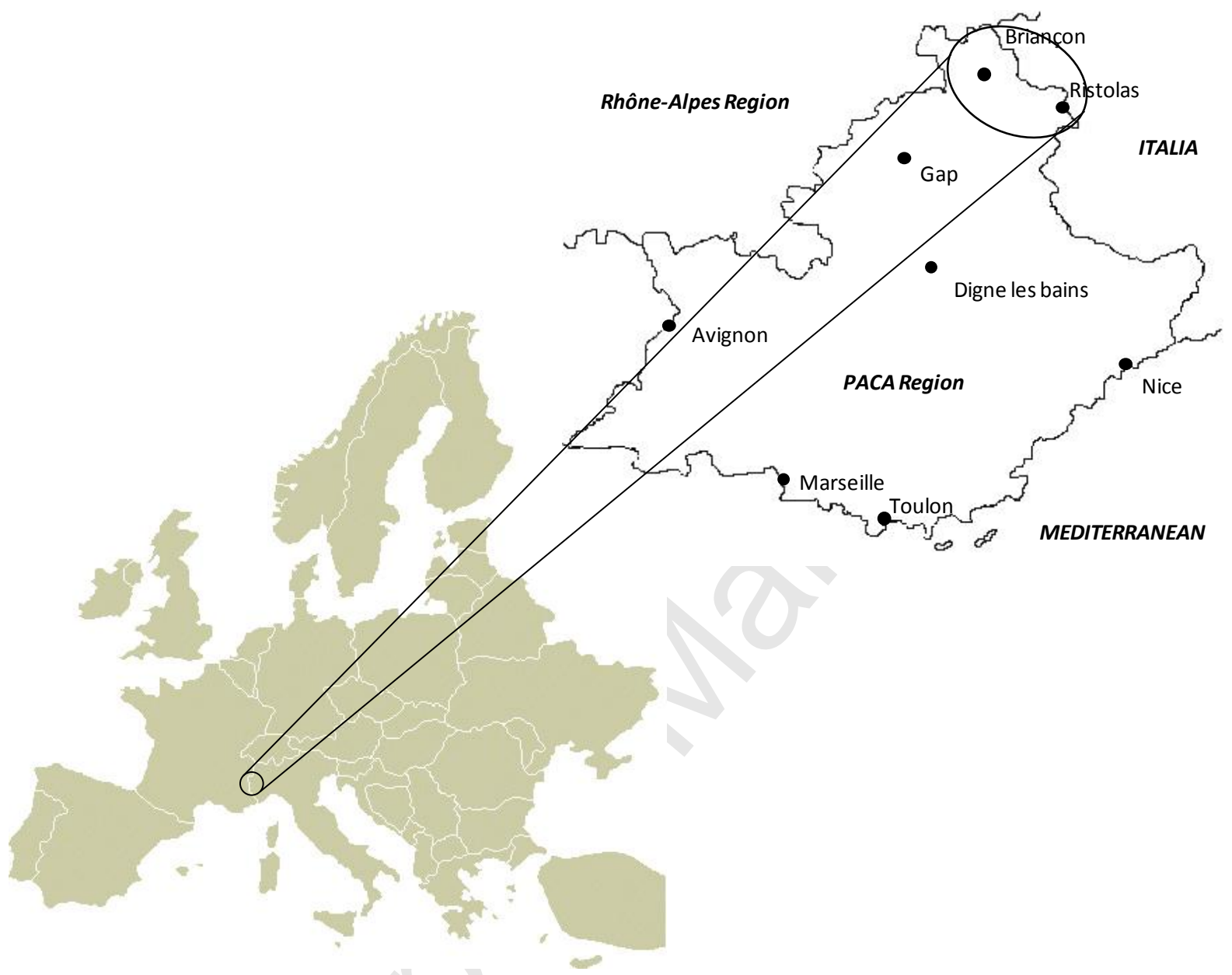

5 
$1 \quad$ Figure 2

2

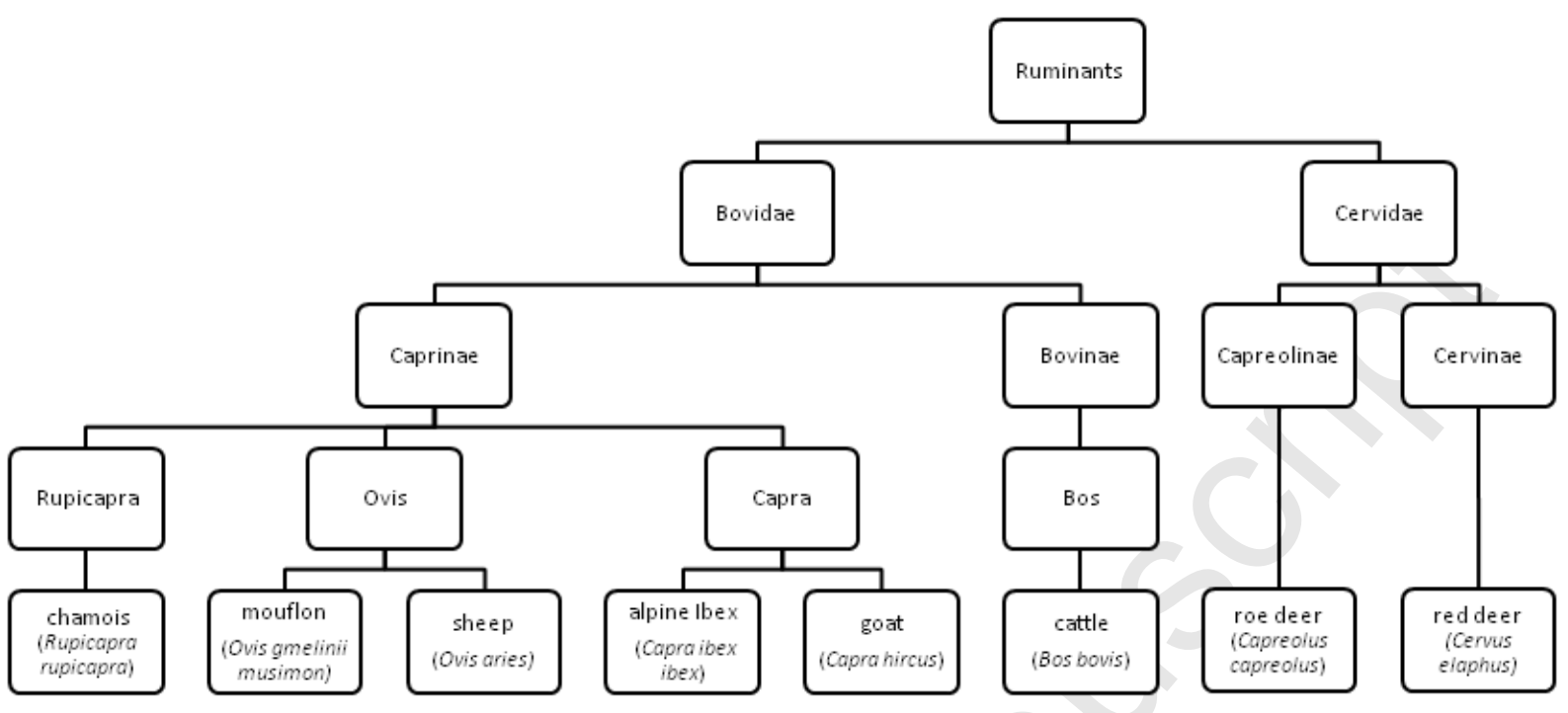

4 
$1 \quad$ Figure 3

2

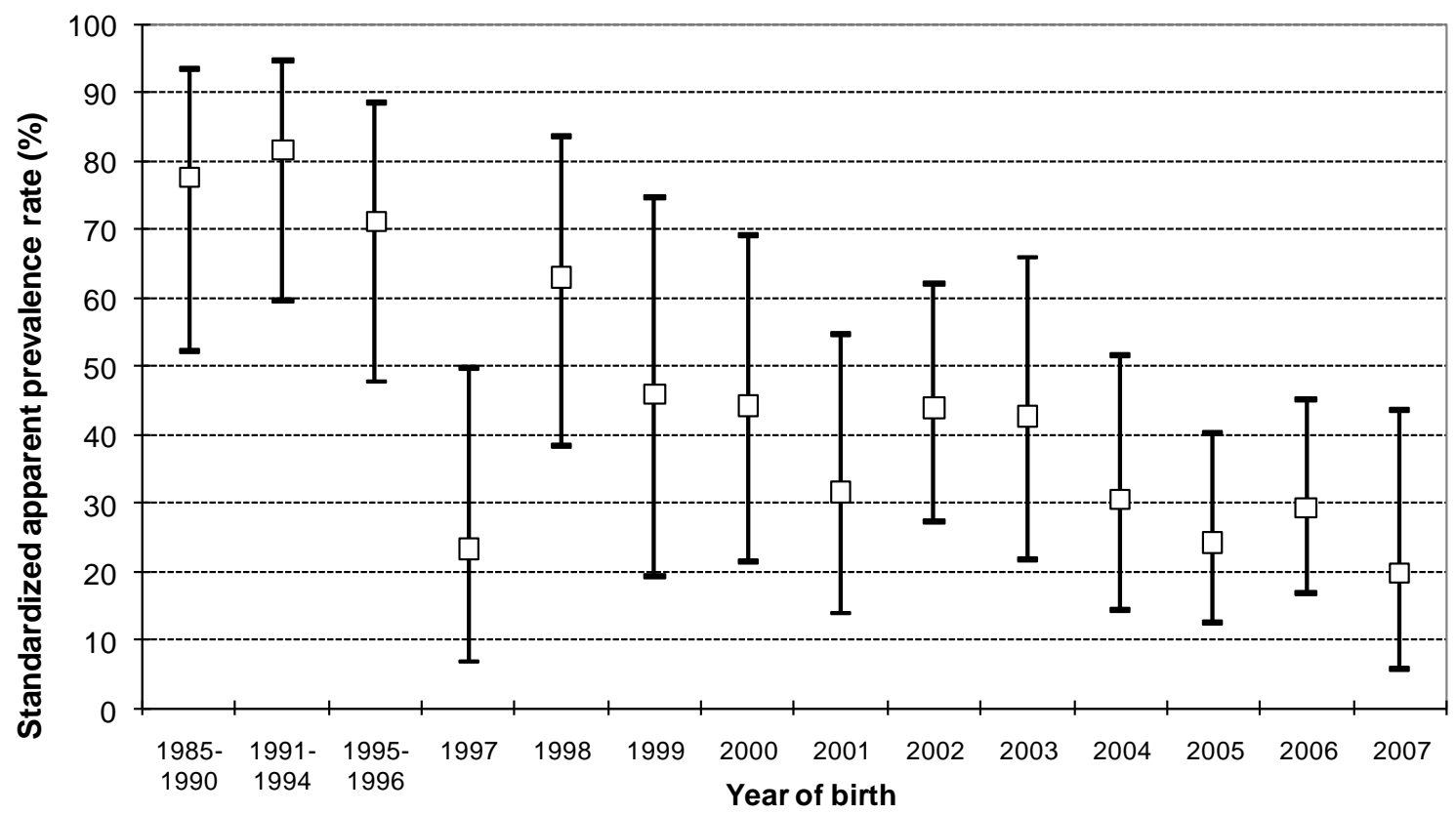

3

4 
Figure 4

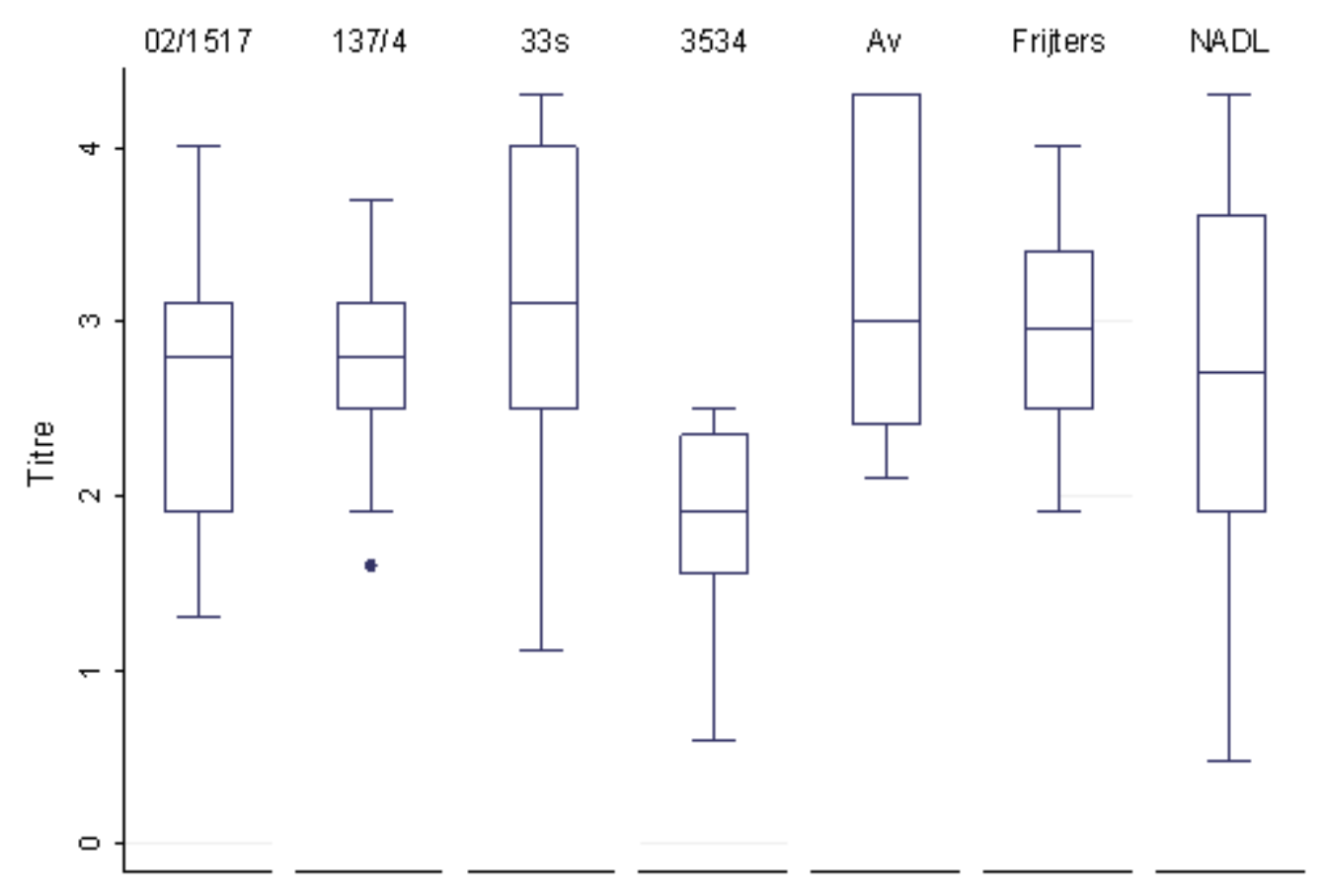

